\title{
Distribution survey of Kloss's Gibbons (Hylobates klosii) in Mentawai Islands, Indonesia
}

\author{
ARIF SETIAWAN ${ }^{1, \vartheta}$, CHRISTIAN SIMANJUNTAK $^{2}$, ISMAEL SAUMANUK ${ }^{3}$, DAMIANUS TATEBURUK ${ }^{3}$, \\ YOAN DINATA ${ }^{2}$, DARMAWAN LISWANTO' ${ }^{2}$, ANJAR RAFIASTANTO ${ }^{2}$ \\ ${ }^{1}$ Swaraowa. Kalipenthung, Kalitirto, Berbah, Sleman 55573, Yogyakarta, Indonesia. "email: a.setiawan@swaraowa.org \\ ${ }^{2}$ Fauna and Flora International Indonesia. Jl. Margasatwa Raya, Komplek Margasatwa Baru No. A7, Pondok Labu, Cilandak, Jakarta Selatan 12450, \\ Jakarta, Indonesia \\ ${ }^{3}$ Malinggai Uma Tradisional Mentawai. Dusun Puro 2, Desa Mailepet, Kecamatan Siberut Selatan, Kepulauan Mentawai 25393, West Sumatra, Indonesia
}

Manuscript received: 6 February 2020. Revision accepted: 26 April 2020.

\begin{abstract}
Setiawan A, Simanjuntak C, Saumanuk I, Tateburuk D, Dinata Y, Liswanto D, Rafiastanto A. 2020. Distribution survey of Kloss's Gibbons (Hylobates klosii) in Mentawai Islands, Indonesia. Biodiversitas 21: 2224-2232. The aim of this study was to assess the population density, distribution, habitats, and threats of Kloss's gibbon (Hylobates klossii) in the Mentawai Islands, Indonesia. In 20112012 we conducted a survey on Siberut Island, outside of the National Park, as well as a short visit to Sipora, North Pagai, and South Pagai. From March to September 2017, we surveyed once again some previous localities on the Siberut and Sipora islands to keep up to date with recent developments on the ground. On Siberut we used an auditory sampling method through fixed point counts, combined with line transects, to estimate the gibbon densities. In total, 113-morning calls were recorded from 13 Listening Points; 75 of these were used for density calculations. We recorded 35 individuals based on direct sightings during $66.4 \mathrm{~km}$ of transect distance walked. We found 13 localities outside of Siberut National Park that still have Kloss's gibbons; densities varied between $1.04 \mathrm{group} / \mathrm{km}^{2}$ to 4.16 group $/ \mathrm{km}^{2}$. No gibbons were found and heard during the short survey in Sipora and South Pagai, though we found a group of gibbons in North Pagai. Our 2017 survey revealed massive habitat changes in South Siberut. Previously existing forest localities in South Siberut were gone due to road construction, agriculture expansion, and logging.
\end{abstract}

Keywords: Auditory sampling, conservation, distribution, Gibbon, Mentawai

\section{INTRODUCTION}

The Kloss's Gibbon (Hylobates klossii Miller, 1903) is endemic to the Mentawai Islands, located off the west coast of Sumatera, Indonesia. The gibbons are distributed among four islands: Siberut, Sipora, South Pagai, and North Pagai (Whittaker and Geismann 2008; Rowe and Myers 2016). The gibbon is sexually monochromatic, with black pelage and skin color (Dooley et al. 2013). It is known by Mentawai indigenous populations as Bilou and nationally named Siamang Kerdil (Supriatna and Ramadhan 2016; Indrizal 2016). Its body size is similar to that of other Hylobatid species (Koda 2016; Burman-Hall 2017).

The Mentawai islands are occupied by five endemic primates: Kloss's Gibbon, Mentawai leaf monkey (Presbytis potenziani, Bonaparte, 1856), Pig-tailed Langur (Simias concolor, Miller, 1903), Siberut Macaque (Macaca siberu, Wilting et al. 2012), and Pagai Macaque (Macaca pagensis, Miller 1903; Paciulli 2010; Roos et al. 2014; Whittaker 2006). The macaques were considered a single species until differentiated in recent decades (Malaivijitnond et al. 2012; Richter et al. 2013).

The gibbon in Mentawai is endangered, predominantly due to habitat loss from extensive legal and illegal deforestation, for agriculture and hunting (Whittaker. 2005a; Whittaker 2006; Quinten et al. 2014; Supriata et al.2017). In the 1980s, it was estimated that there were 36,000 individuals in the Mentawai Islands in Indonesia
(World Wildlife Fund, 1980). In 2005, an assessment estimated that 20,000-25,000 Kloss's gibbons remained, most of them (18,000-21,000 gibbons) located in Siberut National Park-800 individuals in Sipora and 1,700-1,900 in North and South Pagai islands (Whittaker 2006). More recent population estimates conducted in 2011 found that the population trend of Kloss's gibbon has fallen from 19,500 individuals to 10,484 individuals in the whole of Siberut National Park (Whittaker 2006; Quinten et al. 2016).

Whitten (1982) estimated a density of 10.5 individuals $/ \mathrm{km}^{2}$ in Siberut. Paciulli (2004) conducted linetransect surveys in the Pagai Islands to determine the effects of logging, hunting, and vegetation density and diversity on the densities of all four Mentawai primates. She found Kloss's Gibbon densities to be 1.09-1.63 individuals $/ \mathrm{km}^{2}$ and estimated that there were 2,029 gibbons on the Pagai Islands. Whittaker (2005b) found the lowest observed density during her survey (0.88-1.04 groups $/ \mathrm{km}^{2}$ ) was in Taileleu, South-West Siberut, where hunting pressure and collecting non timber forest product use appeared to be very high. A study in Peleonan forest, north of Siberut (ca. $12 \mathrm{~km}^{2}$ ), found 1.0 individuals $/ \mathrm{km}^{2}$ of gibbon density (Quinten et al. 2010). Another recent study in Peleonan forest found gibbon densities to be 3.5-6.5 groups $/ \mathrm{km}^{2}$ (Hoing et al. 2013), and a study in Siberut National Park concluded a density estimate of 6.3 individuals $/ \mathrm{km}^{2}$ (Quinten et al. 2016). The latest study in 
Sipora and Pagai Islands recorded densities estimate 2.3 and 1.9 individual $/ \mathrm{km}^{2}$ (Yanuar and Supriatna 2018).

In the present study, we surveyed the forested areas of Mentawai Island (excluding Siberut National Park) to assess the current distribution of, and threats to, the Kloss's Gibbon. By updating the status in the Mentawai islands, we hope to contribute not only to global knowledge of Kloss's gibbon but also to determine site priorities outside of protected areas for the conservation of this species in the wild.

\section{MATERIALS AND METHODS}

In January and February 2011, we began preliminary surveys and collected information on Kloss's Gibbons in Mentawai Island based on previous studies and reports (see Table 1). We then visited villages in Siberut, Sipora, and North and South Pagai (see maps) and surveyed the forest nearby the village site. This provided qualitative information collected by informal interviews with the villagers, such as Kepala Desa (village heads), Kepala Dusun (village chiefs), Pendeta (Pastors), Sikerei (traditional leader), and active hunters. We selected these as a representative of the local community and their interactions with the forest.

From the beginning of April 2011 until the end of June 2011, we conducted our field surveys. Our surveys for primates were performed predominantly in Siberut Island. Thus, we analyzed gibbon density in Siberut (outside of Siberut National Park) and surveyed presence and absence for Sipora and the Pagais. Three-month surveys were performed in forest areas near 24 villages throughout Siberut; we established 13 Listening Points (LPs), and stayed in each LP for at least four consecutive days, in fragmented forest areas outside of Siberut National Park (see Figure 1).

From May-September 2017, we conducted a survey to understand the latest situation with a visual observation on previous locations covered in the 2011-2012 survey: in Southern Siberut (Majobulu, Batmara, and Raragad Leleu) near to Muara Siberut; in South-West Siberut where we visited a forested site in Tololago village; and on Sipora island where we surveyed the ex-logging area of Simaombuk in the district of North Sipora.

We combined line-transect surveys (Hoing et al. 2013) and auditory sampling using the fixed point count methodology (Setiawan et al. 2012; Cheyne et al. 2016; Gilhooly et al. 2015; Brockelman 2019) to determine the distribution and abundance of the gibbons. First, a field assistant undertook three weeks of training to enable the implementation of this method, particularly to estimate the distance of gibbon calls, using GPS and a compass. We set our campsites as LPs in the forest, located at the ridge top. Starting at $2.00 \mathrm{~h}$ to $9.00 \mathrm{~h}$, we listened for any gibbon calls from the LPs. Previous studies reported that male Kloss's Gibbon started calling at $02.00 \mathrm{~h}$. and females started at sunrise $(06.00 \mathrm{~h})$ (Whittaker 2005a; 2005b). We recorded the direction of the Gibbons' call, the weather in the morning, the starting and end time of the call, and estimated the distance from our LPs.

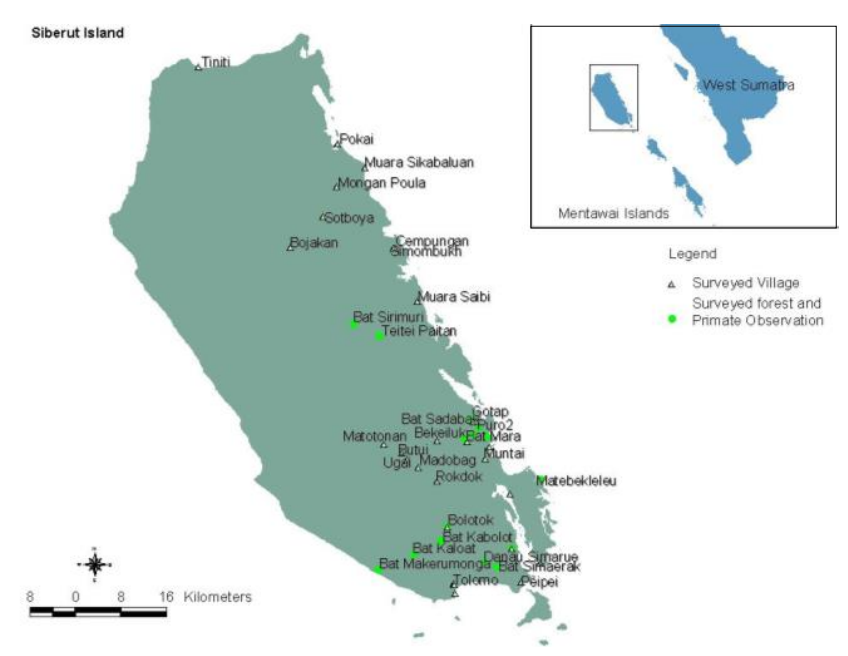

Figure 1. Map of Siberut Island and visited locations, Indonesia

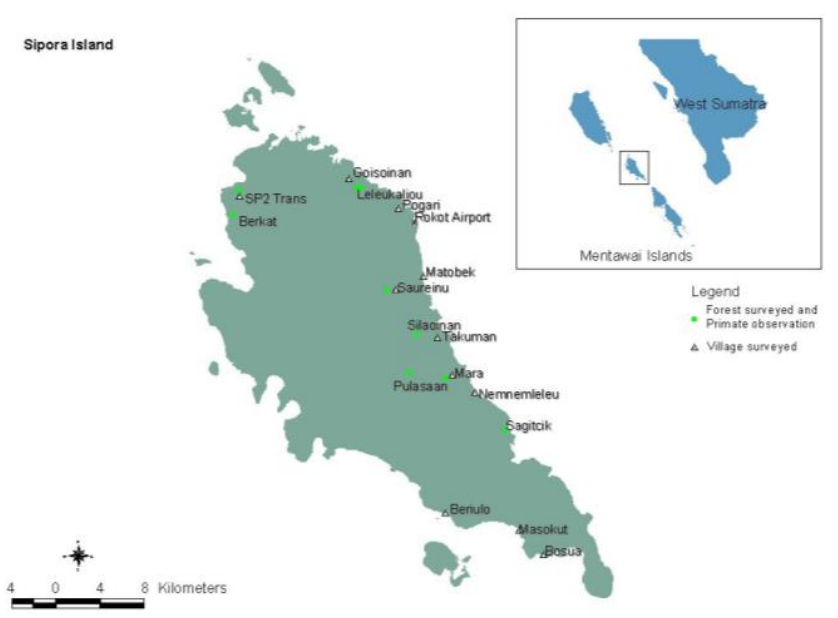

Figure 2. Survey sites in Sipora Island, Indonesia

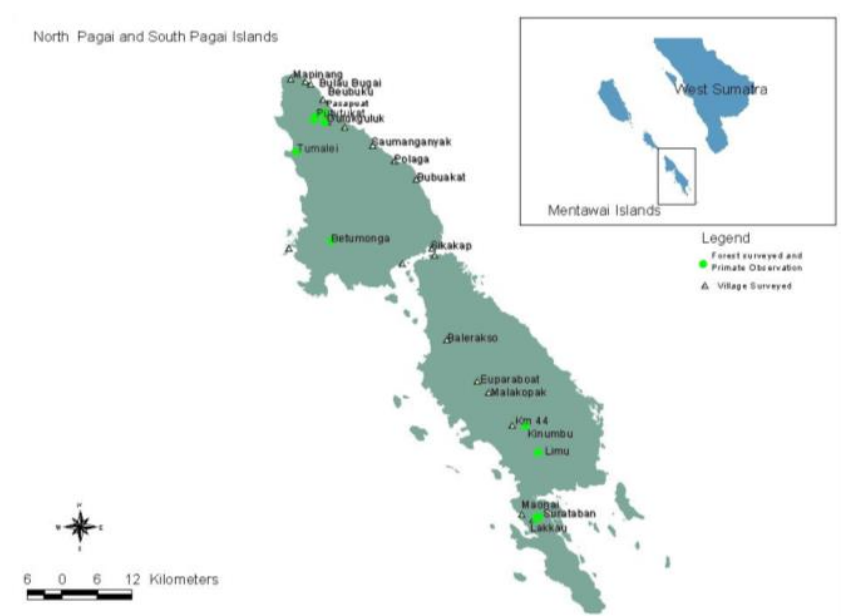

Figure 3. Survey sites in North Pagai and South Pagai, Indonesia 
The line-transect surveys started at $9.00 \mathrm{~h}$, or after the gibbon calls ceased. The transect system was based on four cardinal directions (North-South and East-West) at $1.5 \mathrm{~km}$ length, and we walked twice both directions on each transect, so the total length of the transect in each site was $12 \mathrm{~km}$. We were not able to make this transect system at all of the LPs due to time constraints and insufficient personnel (total 13 LPS established; four LPs with the transect system and nine LPs we used existing trails). Instead, we collected data through broad surveys across forest patches from the non-replicated forest. Walks were conducted mostly cross-country, or were not possible, on established bush trails. This method involves slow, quiet walking, which stops every $50 \mathrm{~m}$ to visually scan the forest and listen for sounds. All recorded data were noted down on pre-prepared worksheets.

Density calculations followed the established auditory sampling or vocalization survey through fixed point count methodology, as previously employed on Kloss's Gibbons in the Mentawais (Whittaker 2005b). We used the formula $D=n / p(m) A$, where $D=$ estimated density, $n=$ number of groups heard, $p(m)=$ proportion of groups expected to sing during sample period $m$, and $A=$ size of the listening area. $n$ is equal to the highest number of groups heard on any one day (Brockelman 2019). For maximum population estimates, we used $p(m)=0.85$ that calculated based on $85 \%-90 \%$ of probability calling other gibbon species during three days observation and calculated the densities of each site where we stayed for at least four consecutive days (Whittaker 2005; Brockelman 2019). Due to time constrain, it was not possible empirically to estimate $p(m)$ that required 8-10 days in each site, and we used $p(m)$ as the same with Whittaker 2005b, for Kloss's Gibbon. We used the same best reliability distance as in Whittaker's study, i.e., gibbon calls within the $600 \mathrm{~m}$ radius that we use for gibbon density calculations (Whittaker 2005b). Data from the line transect survey, as a direct sight method, obtained information not only on the Kloss's Gibbon but also on sympatric primate species - the Siberut/Pagai Langur, the Siberut/Pagai Macaques, and the Pig-tailed langur - providing information on group size and composition, habitat used, and additional ecological observations. We recorded the GPS coordinates where primates were observed and recorded the estimated distance from transect to the primates, bearing or direction from the transect, group size, age, class structure (adult, juvenile and infant), and general habitat description. We then analyzed the data based on our encounter rate (Buckland et al. 2010). We were unable to provide a total population estimate due to the lack of information on the size of the habitat area or potential habitat size for the gibbons in all of the Mentawai Islands.

\section{RESULTS AND DISCUSSION}

\section{Siberut Survey}

In total, 113 gibbon calls were recorded, and 75 groups of gibbons heard within the reliable distance of $600 \mathrm{~m}$, and 35 individuals belonging to nine groups were seen directly during the $66.4 \mathrm{~km}$ of transects in the forest. Complete records by locality of the survey areas during the 20112012 fieldwork (gibbons heard, densities, and habitat in each site) are presented in Table.2.

We recorded eight groups of Kloss's Gibbons (group size range 2-6 individuals) and five groups of Mentawai langurs (group size range 1-6 individuals), Mentawai macaques (group size range 4-21 individuals), and Simakobu (group size range 1-4 individuals) during our transect walks. All records are presented in Table 3.

Table.1 Previous Kloss's gibbon studies in Mentawai

\begin{tabular}{|c|c|c|c|c|}
\hline Study Area & Method (efforts) & $\begin{array}{c}\text { Group or individual } \\
\text { density }\end{array}$ & $\begin{array}{c}\text { Total Population } \\
\text { estimates }\end{array}$ & Reference \\
\hline South Pagai and North Pagai & Line transect & 0.83-2.55 (indv./km²) & na & Paciuli (2004) \\
\hline Peleonan North Siberut & Fixed point count, (5 LPS, 16 days) & $2.65-3.13\left(\right.$ group $\left./ \mathrm{km}^{2}\right)$ & $1,060-1,252$ & Whittaker (2005b) \\
\hline Siberut National Park & Fixed point count, ( 1 LPS, 4 days) & $1.77-2.08\left(\right.$ group $\left./ \mathrm{km}^{2}\right)$ & $13,190-15,413$ & Whittaker (2005b) \\
\hline Siberut, outside park & Fixed point count, ( 2 LPS, 10 days) & $0.88-1.04\left(\right.$ group $\left./ \mathrm{km}^{2}\right)$ & $3,960-4,680$ & Whittaker (2005b) \\
\hline Sipora & Fixed point count, ( 1 LPS, 6 days) & $1.77-2.08\left(\right.$ group $\left./ \mathrm{km}^{2}\right)$ & $753-880$ & Whittaker (2005b) \\
\hline North and South Pagai & Fixed point count, (2 LPS, 8 days) & $1.77-2.08\left(\right.$ group $\left./ \mathrm{km}^{2}\right)$ & $1,680-1,974$ & Whittaker (2005b) \\
\hline Takungan Tiniti & Fixed point count & $2.71\left(\right.$ group $\left./ \mathrm{km}^{2}\right)$ & na & Bismark (2006) \\
\hline $\begin{array}{l}\text { Ex-logging Concession } \\
\text { Tiniti }\end{array}$ & Fixed point count & $2.18\left(\right.$ group $\left./ \mathrm{km}^{2}\right)$ & na & Bismark (2006) \\
\hline Northern Siberut (SCP) & Distance sampling & 8.9 (indv./km²) & $60-150$ & Waltert et al. (2008) \\
\hline Northern Siberut (SCP) & Distance sampling $(51.6 \mathrm{~km})$ & 0.98 (indv. $\left./ \mathrm{km}^{2}\right)$ & na & Quinten et al. (2010) \\
\hline Northern Siberut (SCP) & Distance sampling $(155 \mathrm{~km})$ & $14.89\left(\mathrm{indv} . / \mathrm{km}^{2}\right)$ & na & Hoing et al. (2013) \\
\hline Northern Siberut (SCP) & Triangulation (3 LPS, 28 days) & 3.67-6.5 (group $\left./ \mathrm{km}^{2}\right)$ & na & Hoing et al. (2013) \\
\hline Siberut National Park & Distance sampling ( $192 \mathrm{~km})$ & 3.7-10.6 (indv. $\left./ \mathrm{km}^{2}\right)$ & $6,206-17,713$ & Quiten et al. (2015) \\
\hline Sipora and Pagais & $\begin{array}{l}\text { Line transect }(157.5 \mathrm{~km} \text { and } 186.5 \\
\mathrm{km})\end{array}$ & 2.3 and 1.9 (indv. $\left./ \mathrm{km}^{2}\right)$ & na & $\begin{array}{l}\text { Yanuar and Supriatna } \\
\text { (2018) }\end{array}$ \\
\hline
\end{tabular}


Our presence and absence survey among the villages and forested habitats showed that Kloss's Gibbon and Mentawai langur were the most common primates in South and South-west Siberut Island (see Figure 3.). Our interviews with 32 villagers in the various locations found that in general, it is currently difficult to locate primates in the forests, and villagers have to spend many more days in the forest to hunt primates and other animals than they did five years before. Based on field observation and interviews, the hunting of gibbons and other primates is conducted in several ways: 1 . Using a bow and poisoned arrow; 2. Using rifles, occasionally with poisoned bullets; 3. Using dogs - trained dogs have been used to chase the primates if they descend to the ground, the practice was recorded based on direct observation in Bat Simarue, southwest of Siberut; 4 . A combination of all three methods stated above;5. Using live traps, especially for Macaques, consisting of a wooden cage (length $x$ wide $x$ height) of $2 \mathrm{~m}$ x $1.5 \mathrm{~m} \times 1 \mathrm{~m}$, baited and usually targeting all live groups of Macaques (observed in Sipora Island). Upon capture, hunters consume the macaque group one by one.

To locate primates or other animals, the villagers usually go to the forest in groups (two or more people) to locate their sleeping sites in the evening, and in the early morning, they then wait for the opportune time to hunt. Most villagers informed us that recently it has become difficult to find monkeys in the forest near the villages. Hunting for cultural traditions still occurs at a lower frequency. Gibbons are not targeted animals for cultural ceremonies. Some respondents stated that gibbons are their ancestors, and the meat of a gibbon is considered less palatable than that of other primates. Some respondents also said that gibbons are fast-moving animals, and it is difficult to catch them. The gibbons will make noise (alarm calls) if they detect any humans surrounding them. These findings are supported by recent studies that gibbon of Siberut are less hunted than sympatric primate species (Quinten et al. 2014). Primate populations have generally declined, according to interviews conducted with villagers. Respondents informed us that many people hunt primates for subsistence, but some of the respondents also indicated that agricultural expansion had caused habitat loss in Siberut.

\section{Sipora Survey}

We conducted a survey for nine days on Sipora Island. Eight sites were visited; we stayed a night in each village closest to the forest, gathered information on existing gibbons via nonformal interview, and checked the closest forest the next morning. No gibbons were located, and calls were less distinguishable within the eight surveyed sites (see Fig 2.). In the central island region, there are more developed areas, roads, and settlements, so forests scattered near the coastline were visited. We walked on existing trails for approximately $8.7 \mathrm{~km}$, during which we located a group of Pigtailed Langurs, two groups of Pagai Macaques, and a group of Pagai Langurs. The vernacular names for primates were different from the names used for the surveys in Siberut, with the exception of Bilou for Kloss's Gibbon. People in Sipora, North, and South Pagai use the names Atapaipai for the Mentawai Langur (Presbytis potenziani), Siteut for the Pagai Macaque (Macaca pagensis) and Masepsep for the Pig-tailed Langur (Simias concolor). Based on interviews in 10 visited villages, and interviewed), respondents very rarely hear gibbon calls from the villages. An interview with local residents stated that gibbons still exist in the Betumonga villages (Sakaliou 2012. Pers. comm), located in the eastern coastal district of North Sipora.

Table.2. Localities, number of gibbon calls, general habitat, and density calculation of Kloss's gibbon.

\begin{tabular}{|c|c|c|c|c|c|c|c|}
\hline Location, village & Coordinate & Elevation & $\begin{array}{l}\text { Total } \\
\text { days }\end{array}$ & $\begin{array}{c}\text { Total groups } \\
\text { heard }\end{array}$ & $\begin{array}{c}\text { Total group within } \\
600 \mathrm{~m} \text { radius } \\
\end{array}$ & $\begin{array}{l}\text { Group } \\
\text { density }\end{array}$ & Habitat \\
\hline Bat Tololago & 5257959809326 & 45 & 6 & 3 & 1 & 1.04 & $\mathrm{HF}$ \\
\hline Batmara 1 & 5189469829153 & 119 & 7 & 10 & 2 & 2.08 & $\mathrm{HF}$ \\
\hline Gotap & 5187279831945 & 96 & 5 & 10 & 2 & 2.08 & $\mathrm{HF}$ \\
\hline Matebek Leleu & 5307949821327 & 8 & 1 & 4 & & & $\mathrm{HF}$ \\
\hline Batmara 2, Teteisubuk & 5175329828481 & 84 & 4 & 5 & 1 & 1.04 & $\mathrm{HF}$ \\
\hline Bat Simaerak & 5231809805915 & 24 & 4 & 8 & 4 & 4.16 & PS \\
\hline Bat Sadabak & 5200539830492 & 47 & 3 & 5 & 3 & 3.12 & $\mathrm{HF}$ \\
\hline Danau Simarue & 5211499806854 & 23 & 1 & 2 & 2 & 2.08 & PS \\
\hline Bat Kabolot, hulu & 5133119810478 & 37 & 4 & 7 & 2 & 2.08 & HF-ul \\
\hline Bolotok & 5144609813011 & 38 & 1 & 5 & & & $\mathrm{HF}$ \\
\hline Bat Kaloat hulu & 5085669808149 & 23 & 4 & 3 & 1 & & HF-ul \\
\hline Bat Makerumonga & 5024319805484 & 112 & 4 & 11 & 4 & 4.16 & HF-ul \\
\hline Mailepet & 5214179828827 & 46 & 6 & 2 & 2 & 2.08 & $\mathrm{HF}$ \\
\hline Total & & & 50 & 75 & 24 & & \\
\hline Average density & & & & & & 2.39 & \\
\hline
\end{tabular}

Note: HF: hill dry forest, composed of various Dipterocarps, nibung trees (Onchosperm ssp), rattan (Calamus ssp), Ficus spp, usually dry ground, and mountainous terrain. Most of the areas are ex-logging concessions and sometimes are abandoned gardens. Forest trees are usually higher than $15 \mathrm{~m}$. PS: peat swamp forest, freshwater. This habitat is usually low altitude and flat terrain, always wet and has a general floristic composition occupied by medium-high trees (less than 15 meters), pandanus trees, rattan, ficus trees, and shrubs, etc. HF-ul: Dry hill forest in unlogged areas, primary forest. Forests trees are usually very large, more than 25 meters 


\section{South Pagai and North Pagai Survey}

We visited 21 villages and 10-forested areas in these two islands, and spent two days in each forested area, especially in the morning, listening for calls from places of higher elevation while avoiding noisy disturbances such as roads, settlements, and sea waves. After listening activities were finished at $9.00 \mathrm{~h}$, we carried out observations in the forest by following existing trails. Based on direct sightings

We detected Kloss's Gibbons on two occasions. For all primates observed during the 20-day survey on South Pagai Island. We heard the call of the gibbons only on North Pagai Island. The remaining forests were secondary forests and mixed swamp forests, surrounded by agricultural plantations, rice fields, and settlements. The previously forested central island region was now populated by the villages of Baleraksok, Malakopak, Kinumbu, Lakkao, Maonai, and Surataban. These villages are the result of a relocation program from a government policy to mitigate risks and fatalities to coastal communities in the event of tsunamis.

\section{Survey}

Part of the newest series of surveys conducted from April to September 2017, this survey was conducted with a trained team at Uma Malinggai Traditional Mentawai - a local community organization in southern Siberut, which also joined in our previous fieldwork in 2011-2012. The survey covered three locations in southern Siberut (Majobulu, Batmara, and Raragad Leleu), one location in the southwest of Siberut (Tololago), and the ex-logging area in Pujurung-Simaombuk on Sipora island. The total forest trail distance walked during this survey was $23.3 \mathrm{~km}$, and we record all primate occurrence based on both direct visual as well as auditory observation.
The rapid visual assessment shows that habitat conditions have changed significantly since the previous survey in 2011-2012. Initiated in 20216, the development of the Trans-Mentawai Road has been threatening forest habitat in Mentawai island. The planned road will give access to major villages to transport people and goods in Siberut, Sipora, North Pagai, and South Pagai, with a total length of $393.5 \mathrm{~km}$ (Mentawai Kita 2018). The road development project also incentivizes people to open up more forests for settlement and agriculture areas and to chop down trees for houses and buildings from the surrounding forested area.

\section{Discussion}

\section{Siberut Island}

All recorded gibbon calls (heard within a $600 \mathrm{~m}$ radius), male and female, were used to estimate density. However, male calls may represent single floater animals (Whittaker 2011, pers. comm). Male Kloss's Gibbons normally sing in the early morning before dawn, while female Kloss's Gibbons call after dawn (Dooley et al. 2013). Density calculation based on female calls, especially recorded in six locations, was: Batmara 1 (2.08 group $\left./ \mathrm{km}^{2}\right)$; Batmara Teteisubuk (1.04 group $/ \mathrm{km}^{2}$ ); Gotap (2.08 group $/ \mathrm{km}^{2}$ ); Bat Simaerak (4.16 group $/ \mathrm{km}^{2}$ ); Bat Sadabak (3.12 group $/ \mathrm{km}^{2}$ ); and Bat Makerumonga (4.16 group $\left./ \mathrm{km}^{2}\right)$. And male's call density was in Bat Tololago (1.04 group $/ \mathrm{km}^{2}$ ), Danau simarue (2.08 group $\left./ \mathrm{km}^{2}\right)$, Bat Kabolot hulu ( 2.08 group $/ \mathrm{km}^{2}$ ), and Mailepet (2.08 group $\left./ \mathrm{km}^{2}\right)$. In three locations, Matebek lelelu, Bolotok, and Bat Kaloat Hulu) we heard the gibbons but beyond our reliable 600-meter radius.

Table 3. Number of primates observed on the transect in Siberut Island survey

\begin{tabular}{|c|c|c|c|c|c|}
\hline \multirow[t]{2}{*}{ Location, village } & \multirow{2}{*}{$\begin{array}{c}\text { Transect } \\
\text { walked }(\mathbf{k m})\end{array}$} & \multicolumn{4}{|c|}{ Primates observed (group) } \\
\hline & & Hylobates klosii & Presbytis potenziani & Macaca pagensis & Simias concolor \\
\hline \multicolumn{6}{|l|}{ Siberut } \\
\hline Tololago, Katurai & 7.46 & $3(1)$ & $3(1)$ & & \\
\hline Batmara 1, Muntai & 1.4 & $4(1)$ & $1(1)$ & & $1(1)$ \\
\hline Gotap, Saliguma & 1.44 & $4(1)$ & & & $2(1)$ \\
\hline \multicolumn{6}{|l|}{ Matebek Leleu } \\
\hline Batmara 2, Teteisubuk & 1.7 & $3(1)$ & $3(1)$ & & \\
\hline Bat Simaerak. Taileleu & 12 & $9(2)$ & $7(2)$ & & \\
\hline Bat Sadabak, Mailepet-Gotap & & $3(1)$ & & & \\
\hline \multicolumn{6}{|l|}{ Danau Simarue } \\
\hline Bat Kabolot, peipie (ladang) & 4.4 & & & & \\
\hline Bat Kabolot, hulu & 12 & & & & $4(1)$ \\
\hline \multicolumn{6}{|l|}{ Bolotok (ladang) } \\
\hline Bat Kaloat hulu & 9.5 & & & & \\
\hline Bat Makerumonga & 12 & $6(1)$ & & $21(1)$ & $6(2)$ \\
\hline Mailepet 1 & 2 & & & & \\
\hline Teitei Paitan,Sirisurak & 2.04 & $3(1)$ & $6(1)$ & $4(1)$ & \\
\hline Bat Sirimuri, Sirisurak & 0.5 & & & & \\
\hline Total length & 66.44 & & & & \\
\hline Total individuals & & 35 & 20 & 25 & 13 \\
\hline Average group size & & 3.88888889 & 3.3333333 & 12.5 & 2.6 \\
\hline Encounter rate (indv./km) & & 0.52679109 & 0.3010235 & 0.37627935 & 0.1956653 \\
\hline
\end{tabular}


Gibbon call frequency is related to environmental factors (Whitten 1982; Brockelman and Srikosamatara 1993). During our fieldwork in these fragmented areas and unprotected forests, we were cognizant that human activities might influence gibbon behaviors. Tree cutting with chainsaws started as early as $07.00 \mathrm{~h}$, for instance, in some sites such as Batmara, Gotap, and Mailepet. It is possible that hunting activities also affected gibbon-calling behavior, though further studies would be needed to ascertain this. The aforementioned activities did affect our surveys to record gibbon calls, based on our observation hunting activities started in the morning, same time with gibbon active, if any detection on human attendance, gibbon will do alarm call, and flee away from their normal territory.

We compile gibbon density estimates based on previous studies on Mentawai Island since 2005 (Table 7.). Gibbon densities have changed over time and location - there were two localities in this study with higher densities than before, namely Bat Makerumonga and Bat Simaerak (4.16 groups $/ \mathrm{km}^{2}$ ). These two locations are a relative faraway distance from settlements, so not many human activities are present in those areas. The forest in Bat Makerumonga is close to the western coast of Siberut, where hilly terrain dominates, causing these places to also be less hunted and making it harder to cut down trees, thus making higher gibbon density possible. Average gibbon group densities show a decreasing trend since 2005 (See Figure 4) in various locations in the Mentawai island (Whittaker 2005; Bismark 2006; Quinten et al. 2010; and Quinten et al. 2016).

We are concerned as to why, based on our study, density estimates inside the National Park are lower than outside of it. From our observations in the field we know that outside of the National Park, our surveyed locations were mostly close to aquatic habitats such rivers, estuaries, mangroves, and seas, meaning people living in those areas have at least two options to fulfill their income and livelihood needs - from the forest and agro-forest, or from aquatic-based food sources (such as fish, shrimp, crabs, and snails). The latter provides another source of income, hence hunting and other forest gathering activities are less common than with people living inside or close to the National Park. As we know, Siberut National Park has many enclave communities since before the status of the conservation area was established (Whittaker 2006; Nopiansyah et al. 2016), but hunting and agricultural activities still occur, and activities in the forest are also intense.

Group size observation shows a decreasing trend since 2005 to the recent study (see Fig 4.), though our study was conducted over a longer duration of time in the forest $(55$ days) than previous ones. The smaller recorded group size will significantly contribute to lowering population estimates. Population estimates require knowledge of the land area that is a potential habitat for the Kloss's Gibbon. Recent population estimates of Kloss's Gibbons in
Mentawai, conducted in Siberut National Park, fell from 10,484 individuals (Quinten 2016), decreasing 53\% over more than a decade (Whittaker 2005b). We have insufficient data on recent forest cover outside of Siberut National Park and are thus not doing population estimate calculations to extrapolate the densities toward existing forest conditions, but are certainly based on the recent survey that degradation of forest and hunting still occur. Both these factors will contribute to decreasing populations outside of the conservation area in Mentawai Island, and support our finding that group size in this study is smaller than reported by Whittaker in 2005. However, we acknowledge uncertainty with these densities, as issues such as choice of sample sites, duration (days), observers' varying experiences, weather, and logistics will impact data analysis and results.

We found all gibbon groups in secondary habitats, exlogging concessions, and abandoned agriculture areas, with the exception of those in Bat Makerumonga, which were in primary forest. Outside Siberut National Park, gibbon habitats were mostly characterized by fragmented forests, with steep topography and abandoned agricultural areas. Threats to gibbon habitat varied based on location and included road construction, settlements, logging, and agricultural expansion, all of which incontrovertibly threaten remaining forests.

A recent government project has been initiated in Southern Siberut to develop connecting roads to all district areas. This project has increased the establishment of new settlements and land clearing for agriculture. Habitat destruction and degradation due to logging can still be observed in the remaining forested areas, motivated by economic incentives. Forests occupied by tribes or families in Southern Siberut were cleared to build houses, and the timber is used for dugout boats or is sold to people outside the tribe.

The gibbons of Siberut live in fragmented forests scattered in agricultural areas or abandoned fields in dry hilly forest habitats. Hunting for ceremonial or cultural purposes occurred less frequently for gibbons than for other primates, as tribal communities believe that the gibbon is their ancestor or at least a human-like animal. Another reason hunters do not target gibbons is that they move too quickly at the very top of tree canopies, and it is hard to hit them with poisoned arrows. However, gibbons are hunted for food in forests adjacent to agricultural areas where a Mentawaian family usually has been present for several days in the forest garden.

Gibbons was also found to be kept as pets in two villages in Southern Siberut. In Muntai village, an infant gibbon had been captured from the forest by villagers and kept for approximately two months. Another gibbon pet was found in Malilimuk village. It was bought from other villagers for US\$ 36.90. A case of Mentawai gibbon traded to the mainland of Sumatera via Padang port was reported in 2014 (Indrizal 2016). 


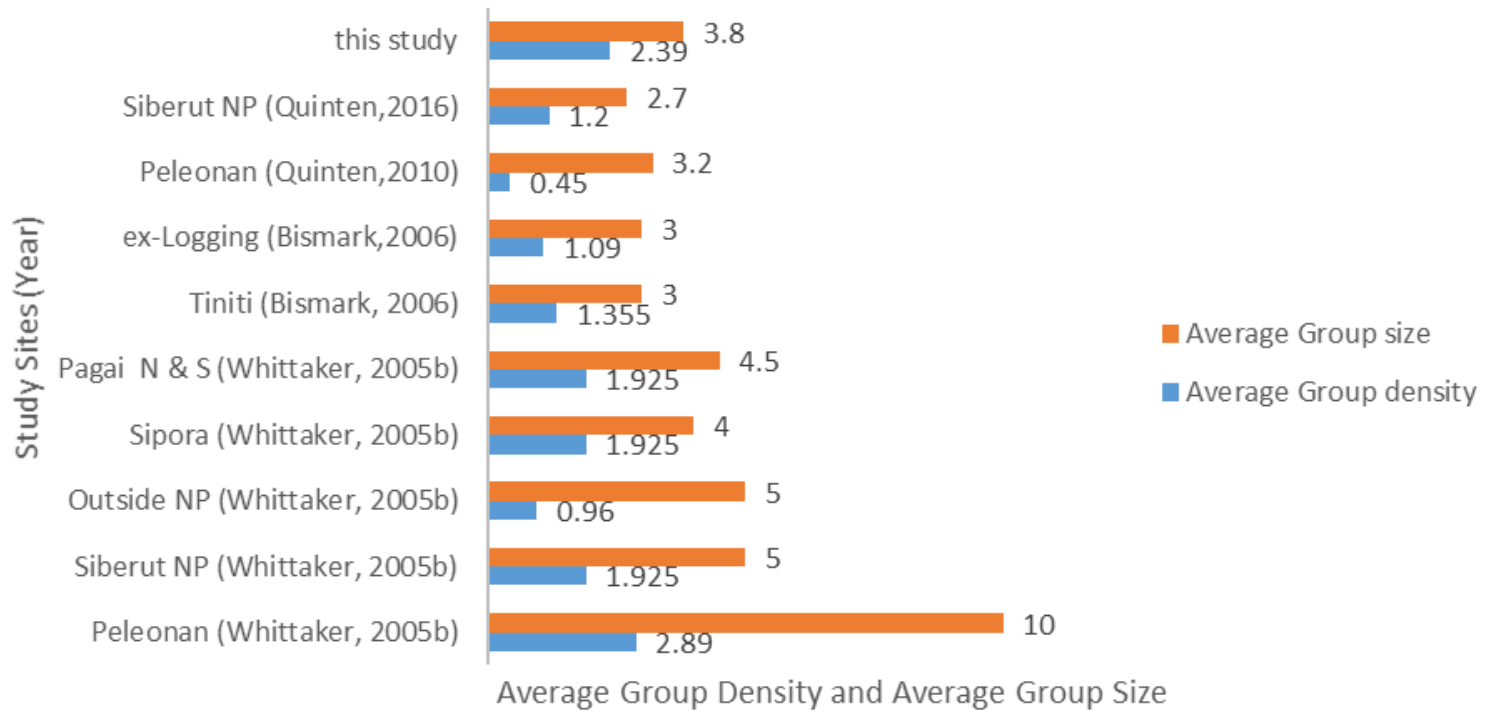

Figure 4. Average group densities and average group size of Kloss's Gibbon over time series

It is difficult to stop hunting practices and agricultural expansion in areas that are remotely located and provide very few options for livelihood. Some villagers realized that gibbons and other primates are animals that cannot be found elsewhere, and some understand that if forest habitats continue to decline, these unique primates will be extirpated from the Mentawai Islands. Some villagers said that they want a better income and believe this can be achieved by farming more intensively on their land plots. Hunting is now considered more time-consuming, and the costs often outweigh the gains. To minimize natural forest resource exploitation, it might help to apply forestfarming/agroforestry methods, which combine existing natural trees with agriculture crops especially suitable to the peat swamp area and Mentawaian culture.

To enhance the value of existing agroforestry products, it is necessary to create ready-made products for daily consumption or, if possible, for a wider market. It is also critically important to build capacity for Mentawaians to manage existing land, and to promote a Mentawaian culture that is strongly linked to nature. It may be considered a marketing strategy to produce and sell agricultural products or even subsistence goods that are sustainably sourced, to increase incomes, and improve livelihoods.

Based on a recent survey in southern Siberut, forested areas along the roadside of the Trans Mentawai Road area have been badly degraded due to hunting, illegal logging and forest conversion for agricultural land. Two locations in Raragad leleu and Tololago are in the best condition for primate abundances and vegetation cover compared to other locations visited, however conservation outlook for primates in these forests remains uncertain.

\section{Sipora Island}

A long history of logging and the presence of logging companies are likely the biggest influence on the Kloss's Gibbon distribution in Sipora Island. It also has an impact on other primate species present. The remaining forests are on very steep-sloped areas that are inaccessible to people. Based on the interviews we conducted, gibbon calls were rarely heard, and no calls were heard during our surveys. Interviews with villagers also revealed that the villagers had not seen gibbons in the forest for a long time, and some of them didn't recognize all the primate species in their forest.

More time and resources are needed to conduct surveys in the forests in Sipora to ascertain if gibbons still remain. The largest forest block is a dry hill forest in the middle of the island - from Goisoinan to Saureinu and Mara village. We were able to directly observe the Pagai Langur, Pagai Macaque, and Pigtailed Langur during transect surveys. The forest block in the middle of the island is surrounded by field gardens, plantations of cloves, and cocoa. In Tuapejat, $7 \mathrm{~km}$ away, we also recorded several primates being kept by residents. These included a Siamang gibbon (Symphalangus syndactylus, Raffles, 1821) brought by people from the mainland of Sumatera, and a Pagai Macaque (Macaca pagensis). Extensive farming for agriculture (cocoa, taro, coconut, and cloves) is the main source of income for villagers. Rehabilitation and reconstruction of new villages in the aftermath of the 2010 tsunami have also opened new road access into forested areas in western Sipora, in areas such as Berioulo, Masokut, and Bosua. Hunting for all primates is still practiced in Sipora. Traditional hunting using poisonous arrows and bows has decreased, and poisonous bullets and baited traps are the current equipment of choice to catch primates. 


\section{North Pagai and South Pagai}

The forest areas in South and North Pagai are predominantly ex-logging concessions. Old Secondary forests can be found in fragmented areas. Gibbons and other primates were observed during forest surveys. Interviews with villagers revealed that gibbons still exist in these forests. Forests in the middle of the island in South Pagai could be found up to Kinumbu village. However, government resettlement programs have brought settlements into forested areas in Mentawai, in addition to the development of permanent evacuation sites and evacuation roads in anticipation of tsunami events, making the remaining forested areas vulnerable to encroachment, hunting and agricultural development (Putra et al. 2016).

This survey provides the latest information on the distribution of the Kloss's Gibbon in Mentawai, especially outside of conservation areas. Based on this survey, Sipora island and the Pagais, where the remaining forest holds great potential for the survival of the gibbons, should be surveyed more intensely. Some forest patches in Siberut Island are occupied by good populations of the gibbons; however, forest conversion and opportunistic hunting are still threats to the survival of the gibbons and other Mentawaian Primates. Mentawai cultures have very related to nature, especially with primates. In Siberut island these cultural practices still applied, however in Sipora and Pagais not too often or even no longer. We noted that there is some local new native organization is established in Siberut and Sipora to revitalize Mentawai cultural value. Through this kind of organization, the value of Mentawai biodiversity, especially primates, can be strengthened. However, need more assistance to build the capacity and institutional management.

Preservation of their remaining native habitat as a sustainable economic source, cultural sources, education, as well as the rejuvenation of knowledge of Mentawai primates amongst younger generations is all critically important.

\section{ACKNOWLEDGEMENTS}

We would like to give thanks and dedicate this writing to the late Dr. Tonny Whitten (Fauna and Flora International), who inspired us to work in Mentawai and was involved in discussions at the first stage of this project. We would like to thanks Dr. Ramesh Bonratana, Dr. Wendy Erb, and Dr. Susan Cheyne who help to improve this manuscript. We are grateful to all the field assistants who worked with us in Yoyok, Robert, Bikin, and Mateus. We thank PERHAPPI through the Symposium and Congress of Indonesian Primates 2019 who provide financial support for publication. The fieldwork in 20112012 was supported by the US Fish and Wildlife Service, and the recent survey in 2017 was supported by the IUCN Primate Specialist Group Special Section on Small Apes, and Wildlife Reserve Singapore.

\section{REFERENCES}

Bismark M. 2006. Konserasi Primata Endemik Mentawai: Analisis Habitat dan Populasi Primata di Siberut Utara, Makalah Utama pada Ekspose Hasil-hasil Penelitian: Konservasi dan Rehabilitasi Sumberdaya Hutan. Padang, 20 September 2006. [Indonesian]

Brockelman WY. 2019. Counting gibbons: The evolution of sample methods. Interdisciplinary Research Review, 14 (6), 21-27.

Buckland ST, Plumptre AJ, Thomas L, Rexstad EA. 2010. Design and analysis of line-transect surveys for primates. Intl J Primatol 31 (5), 833-847. DOI: 10.1007/s10764-010-9431-5.

Burman-Hall L. 2017. Only in Mentawai: Unique Primate Vocalisations and Songs in an Isolated Indonesian Island Group. Shima: The Int J Res Isl Cultures, 11 (2), 116-150, DOI: 10.21463/shima.11.2.10

Cheyne SM, Gilhooly LJ, Hamard MC, Höing A, Houlihan PR, Loken B, Phillips A, Rayadin Y, Capilla BR, Rowland D, Sastramidjaja WJ. 2016. Population mapping of gibbons in Kalimantan, Indonesia: correlates of gibbon density and vegetation across the species' range. Endangered Species Research, 30, 133-143.

Dooley HM, Judge DS, Schmitt LH. 2013. Singing by male and female Kloss gibbons (Hylobates klossii) in the Peleonan Forest, Siberut Island, Indonesia. Primates, 54 (1), 39-48. DOI: 10.1007/s10329-0120326-2

Dooley HM, Judge DS, Schmitt LH. 2013. Singing by male and female Kloss gibbons (Hylobates klossii) in the Peleonan Forest, Siberut Island, Indonesia. Primates 54 (1): 39-48.

Fuentes A. 2002. Monkeys, humans and politics in the Mentawai Islands: no simple solutions in a complex world. Cambridge Studies in Biological and Evolutionary Anthropology, Cambridge University Press, Cambridge.

Gilhooly LJ, Rayadin Y, Cheyne SM. 2015. A comparison of hylobatid survey methods using triangulation on Müller's gibbon (Hylobates muelleri) in Sungai Wain Protection Forest, East Kalimantan, Indonesia. Int J Primatol, 36 (3): 567-582. DOI: 10.1007/s10764-0159845-1.

Höing A, Quinten MC, Indrawati YM, Cheyne SM, Waltert M. 2013. Line transect and triangulation surveys provide reliable estimates of the density of Kloss' gibbons (Hylobates klossii) on Siberut Island, Indonesia. Intl J Primatol 34 (1): 148-156. DOI: 10.1007/s10764-0129655-7.

http://www.mentawaikita.com/berita/1414/progres-jalan-trans-mentawaibaru-1387-km.html [23 May 2018][Indonesian]

Indrizal E. 2016. Bilou dan tantangan mengkonservasinya di Mentawai: sebuah tinjauan dari perspektif sosial budaya. J Antropologi: Isu-Isu Sosial Budaya 18 (1): 51-56. [Indonesian]

Koda H. 2016. Gibbon songs: Understanding the evolution and development of this unique form of vocal communication. In: Evolution of Gibbons and Siamang. Springer, New York.

Malaivijitnond S, Arsaithamkul V, Tanaka H, Pomchote P, Jaroenporn S, Suryobroto B, Hamada Y. 2012. Boundary zone between northern and southern pig-tailed macaques and their morphological differences. Primates, 53 (4): 377-389.

Nopiansyah F, Basuni S, Purwanto Y, Kosmaryandi N. 2016. Forest resource utilization by the Siberut community and its implications for the Siberut Island Biosphere Reserve Policy. J Manajemen Hutan Tropika 22 (2): 94-104.

Paciulli LM. 2010. The Relationship Between Nonhuman Primate Densities and Vegetation on the Pagai, Mentawai Islands, Indonesia. In: Gursky S, Supriatna J. (eds.). Indonesian Primates. Developments in Primatology: Progress and Prospects. Springer, New York.

Putra A, Mutmainah H. 2016, November. The Mapping of Temporary Evacuation Site (TES) and Tsunami Evacuation Route in North Pagai Island, Mentawai Islands Regency-Indonesia. IOP Conf Ser Earth Environ Sci 47: 012020. DOI: 10.1088/1755-1315/47/1/012020

Quinten M, Stirling F, Schwarze S, Dinata Y, Hodges K. 2014. Knowledge, attitudes and practices of local people on Siberut Island (West-Sumatra, Indonesia) towards primate hunting and conservation. J Threatened Taxa 6 (11): 6389-6398.

Quinten MC, Nopiansyah F, Hodges JK. 2016. First estimates of primate density and abundance in Siberut National Park, Mentawai Islands, Indonesia. Oryx 50 (2): 364-367.

Quinten MC, Waltert M, Syamsuri F, Hodges J K. 2010. Peat swamp forest supports high primate densities on Siberut Island, Sumatra, Indonesia. Oryx 44 (1): 147-151. 
Richter C, Taufiq A, Hodges K, Ostner J, Schülke O. 2013. Ecology of an endemic primate species (Macaca siberu) on Siberut Island, Indonesia. SpringerPlus 2 (1): 137.

Roos C, Boonratana R, Supriatna J, Fellowes JR, Groves CP, Nash SD, Rylands AB, Mittermeier RA. 2014. An updated taxonomy and conservation status review of Asian primates. Asian Primates J 4 (1): 2-38

Rowe N, Myers M. 2016. All the world's primates. The International Encyclopedia of Primatology, Pogonias Press; UK.

Setiawan A, Nugroho TS, Wibisono Y, Ikawati V, Sugardjito J. 2012 Population density and distribution of Javan gibbon (Hylobates moloch) in Central Java, Indonesia. Biodiversitas 13 (1): 23-27. DOI: 10.13057/biodiv/d130105.

Supriatna J, Dwiyahreni AA, Winarni N, Mariati S, Margules C. 2017. Deforestation of primate habitat on Sumatra and adjacent islands, Indonesia. Primate Conserv 31: 71-82.

Supriatna J, Ramadhan R. 2016. Pariwisata Primata Indonesia. Yayasan Pustaka Obor Indonesia, Jakarta. [Indonesian].

Whittaker D, Geissmann T. 2008. Hylobates klossii. The IUCN Red List of Threatened Species 2008: e.T10547A3199263. DOI
10.2305/IUCN.UK.2008.RLTS.T10547A3199263.en. [29 November 2017].

Whittaker DJ. 2005a. Evolutionary genetics of Kloss's gibbons (Hylobates klossii): systematics, phylogeography, and conservation. [Dissertation]. City University of New York Graduate Center, New York.

Whittaker DJ. 2005b. New population estimates for the endemic Kloss's gibbon Hylobates klossii on the Mentawai Islands, Indonesia. Oryx 39 (4): 458-461.

Whittaker DJ. 2006. A conservation action plan for the Mentawai Primates. Primate Conserv 20: 95-105.

Whitten AJ. 1982. The ecology of singing in Kloss gibbons (Hylobates klossii) on Siberut Island, Indonesia. Intl J Primatol 3: 33-51.

Wilting A, Sollmann R, Meijaard E, Helgen KM, Fickel J. 2012. Mentawai's endemic, relictual fauna: is it evidence for Pleistocene extinctions on Sumatra?. J Biogeogr 39 (9): 1608-1620.

World Wildlife Fund. 1980. Saving Siberut: A Conservation Master Plan. WWF Indonesia Programme, Bogor

Yanuar A, Supriatna J. 2018. The Status of Primates in the Southern Mentawai Islands, Indonesia. Primate Conserv 32 (1): 193-203. 